\title{
Research on Social Work Practice
}

http://rsw.sagepub.com

\section{ACORN's Accelerated Income Redistribution Project: A Program Evaluation \\ Fred Brooks, Daniel Russell and Robert Fisher \\ Research on Social Work Practice 2006; 16; 369 \\ DOI: $10.1177 / 1049731505285673$ \\ The online version of this article can be found at: http://rsw.sagepub.com/cgi/content/abstract/16/4/369}

\author{
Published by: \\ (SAGE \\ http://www.sagepublications.com
}

Additional services and information for Research on Social Work Practice can be found at:

Email Alerts: http://rsw.sagepub.com/cgi/alerts

Subscriptions: http://rsw.sagepub.com/subscriptions

Reprints: http://www.sagepub.com/journalsReprints.nav

Permissions: http://www.sagepub.com/journalsPermissions.nav

Citations http://rsw.sagepub.com/cgi/content/refs/16/4/369 


\title{
ACORN's Accelerated Income Redistribution Project: A Program Evaluation
}

\author{
Fred Brooks \\ Georgia State University School of Social Work \\ Daniel Russell \\ Springfield College \\ Robert Fisher \\ University of Connecticut School of Social Work
}

\begin{abstract}
Objective: This study evaluated the Association of Community Organizations for Reform Now's (ACORN) efforts to increase the uptake of families claiming the earned income tax credit through door-to-door canvassing and managing free tax preparation clinics in three pilot cities. Method: The mixed-method program evaluation included administrative record review, a telephone survey $(\mathrm{N}=1,063)$, and individual and focus group interviews. Results: During the 2003 tax year, ACORN prepared taxes at no charge for 3,850 families who collected a total of \$4 million in earned income tax credit and other tax credits. In two pilot cities, ACORN led all other free sites in number of returns filed. Canvassing and word of mouth were the most productive marketing tools for the free tax preparation sites. Conclusions: Canvassing appears to be effective outreach in getting families to take advantage of free tax preparation. ACORN's approach to combining services and direct action organizing appears to be a good fit and sustainable.
\end{abstract}

Keywords: Association of Community Organizations for Reform Now; earned income tax credit; community organizing; voluntary income tax assistance

The earned income tax credit (EITC) is the nation's single most effective poverty reduction program for people less than 65 years old. In 2003, 21 million families received EITC tax refunds totaling more than 36 billion dollars (U.S. Government Accounting Office [GAO], 2005). Every year, the EITC moves approximately five million individuals above the federal poverty line, about half of them children (Llobrera \& Zahradnik, 2004). Lowincome families, however, are failing to claim additional billions of potential EITC benefits. In 1999, 4.3 million eligible families did not claim $\$ 2.7$ billion of EITC refunds (U.S. GAO, 2001). The IRS estimates $25 \%$ of families who qualify for the EITC fail to claim the tax credit (U.S. GAO, 2005), more than any other benefit in the tax code. The aggressive marketing of refund anticipation loans (RALs) by commercial tax-preparation companies also reduces the amount low income working

Authors'Note: This research was funded by a grant from the Marguerite Casey Foundation. Correspondence may be addressed to Fred Brooks, PhD, School of Social Work, Georgia State University, P.O. Box 3995, Atlanta, GA 303023995; e-mail Fbrooks2@gsu.edu.

Research on Social Work Practice, Vol. 16 No. 4, July 2006 369-381 DOI: $10.1177 / 1049731505285673$

(C) 2006 Sage Publications families receive from their tax returns. RALs, short-term high interest loans that allow taxpayers to receive their federal tax refunds in 0 to 2 days, generate approximately $\$ 1$ billion a year in revenues for tax preparation companies (Wu, Fox, \& Reunart, 2002). Of all EITC filers in 1999, 39\% got their refund through a RAL (Berube, Kim, Forman, \& Burns, 2002).

In response to the billions of EITC dollars being lost to low income families, the Association of Community Organizations for Reform Now (ACORN) piloted the Accelerated Income Redistribution (AIR) campaign in New Orleans, LA, Miami, FL, and San Antonio, TX in 2004. With a broad goal of increasing the incomes of lowincome employed families, the AIR campaign involved (a) engaging in extensive door-to-door canvassing to inform families of free tax preparation sites and screen families for potential EITC eligibility, (b) opening and managing free tax preparation sites (also called Voluntary Income Tax Assistance [VITA] sites), and (c) organizing direct action campaigns against the predatory lending practices of H\&R Block, the nation's largest tax preparation company and the issuer of the most RALs.

In this article, we evaluate the first two components: (a) the effectiveness of ACORN's canvass to influence 
low-income tax payers' decisions to file taxes at a VITA site as opposed using a commercial tax preparation company and (b) the productivity of ACORN's VITA sites in terms of the number of tax returns filed and the percentage of clients claiming the EITC. Although the direct action campaign against H\&R Block's RALs was an integral part of the AIR project, a thorough evaluation of the anti-RAL campaign is beyond the scope of this article.

\section{BACKGROUND AND LITERATURE REVIEW}

\section{Legislative and Political History of EITC}

The EITC was created in 1975 during the Ford administration to offset the social security payroll taxes paid by low-income employed parents and to encourage parents to work in the labor force. To obtain the EITC, an eligible person must work and file federal income taxes. Unlike other tax credits, the EITC is a refundable credit; this allows a tax payer to obtain a refund even if he or she does not owe any federal tax payments. The EITC has a phasein and phase-out range where the credit increases or decreases based on income and family size. For tax year (TY) 2003 (applicable to this evaluation), the maximum benefit was $\$ 4,300$; the maximum annual income allowed was $\$ 35,458$ (Center on Budget and Policy Priorities, 2004).

The EITC has been revised and expanded five times during the past 30 years. In 1978, during the Carter administration, the credit was made permanent and an advance payment option was created. During the Reagan administration, the Tax Reform Act of 1986 indexed the EITC to inflation (Beverly, 2002). In 1990 (during the George H.W. Bush administration), the Omnibus Budget Reconciliation Act increased the credit and separated it into two schedules depending on family size. Under President Clinton, the Omnibus Budget Reconciliation Act of 1993 further expanded the EITC and added a third schedule for low-income families with no children (Phillips, 2001). The final expansion of the EITC was through the Economic Growth and Tax Relief Reconciliation Act of 2001 (during the present Bush administration), which increased benefits for married families with children and will be phased in between 2002 and 2008 (Beverly, 2002).

A remarkable feature of the tax credit during the past 30 years has been the EITC's popularity across the political spectrum, with "liberals and conservatives, the President, Congressional leaders, disparate political interests, and powerful political communities" (Ventry, 2000, p. 1015). One reason the EITC has received strong bipartisan support during the years is because it is typically perceived as both anti-welfare and anti-poverty (Ventry, 2000).

\section{EITC Effects on Poverty and Work}

The EITC has effects on income and poverty, consumption, household development, and employment. Scholz and Levine (2000) estimate that $60 \%$ of EITC payments go to families who would be poor if they did not receive the tax credit. In 2002, it lifted nearly five million people, nearly half of them children, out of poverty, more than any other Federal program (Llobrera \& Zahradnik, 2004). EITC reduces income inequality and poverty, helps the poor build assets, and promotes employment because it targets the working poor (Wu et al., 2002). In 2003, the IRS estimates that approximately 21 million families received EITC tax refunds totaling more than 36 billion dollars.

Because families typically receive the EITC in a lump sum during the tax season, it influences consumption patterns differently than other types of cash aid. In a study of how families planned to use EITC refunds, Smeeding, Phillips, and O'Conner (2000; also in Beverly, 2002) found $37 \%$ of respondents planned to use their tax refunds to pay utility bills, $34 \%$ planned to pay rent, $22 \%$ planned to purchase clothing, and $21 \%$ planned to purchase food. According to Beverly (2002), "Research also suggests that families use tax refunds to save, to purchase or repair cars and homes, to make credit card and other debt payments and to pay for education expenses" ( $p$. 262).

Because the EITC has a phase-in and phase-out range where benefits increase with income to a point and then decrease with additional income, the effects of EITC on employment are complex. In a review of studies, Hotz and Scholz (2001; also discussed in Beverly, 2002) concluded that the EITC encourages individuals in singleparent families to begin working in the labor force.

Thus, EITC is an important poverty reduction program that is effective, politically popular, unusual in its impact, and widely underused.

\section{FAMILIES WHO QUALIFY BUT DO NOT CLAIM EITC}

Not all families eligible for EITC apply for the tax refund. Despite its obvious benefits to potential recipients, the U.S. GAO (2001) estimates that $25 \%$ of eligible families do not apply for EITC, the largest percentage of 
any benefit the tax code offers. Scholz's 1994 study of this phenomenon concluded that there are three major reasons why. First, an eligible taxpayer may have failed to file income tax or cheated in the past. Second, the eligible taxpayer may feel that filing for EITC is more of an inconvenience than the amount of money from the return. Third, some eligible taxpayers may not be aware of the EITC. Individual characteristics correlated with nonparticipation include the following: receiving income from social security and public assistance, having a larger family, being unmarried, being male, and being of Hispanic origin. Nonparticipation also increases when "taxpayers are entitled to a smaller EITC, have a greater share of earnings composed of self-employment income, live in states without state income taxes, work in household service occupations, and have higher levels of education" (Scholz, 1994, p. 11).

\section{ACORN and the AIR Campaign}

Founded in 1970, ACORN has grown considerably during 35 years. ACORN's model of organizing is well documented in the literature (see Adamson \& Borgos, 1984; Brooks, 2001; Delgado, 1986; Fisher, 1994; Kest \& Rathke, 1979; Russell, 1990; Staples, 2004; Stein, 1986). ACORN organizes democratically run neighborhood organizations of low and moderate income families that engage in confrontational tactics to challenge the power structure and win victories on issues such as city services, utility rates, tenants rights, environmental hazards, affordable housing, living wages, access to bank loans, predatory lending, and public education. Several aspects of ACORN's organizing model are unique among community organizations. First, ACORN organizes the unorganized. "Departing from the Alinsky tradition of organizing people through institutional networks (typically churches), ACORN goes door-to-door and signs-up members regardless of their institutional connections" (Brooks, 2005, p. 265). Second, ACORN has a federated national structure that allows it to organize simultaneously on neighborhood, city, state, and national issues. ACORN is one of the few grassroots neighborhood organizations capable of wielding power on a national scale (Atlas \& Dreier, 2003; Brooks, in press).

In addition to engaging in the direct action campaigns for which it is best known, ACORN provides a number of direct individual services to its members and constituents. ACORN offers mortgage counseling tailored to low-income, first-time home buyers, tenants' rights counseling, and welfare benefits case advocacy (Brooks, 2001). With the AIR campaign, ACORN decided to test a new service to its constituency. It offered free tax preparation targeting families that would potentially qualify for the EITC. In May 2003, ACORN applied to the Marguerite Casey Foundation to fund pilot demonstrations of the AIR campaign for New Orleans, Miami, and San Antonio. IRS statistics suggested these cities contained large numbers of EITC-eligible families who were not applying for the tax refund. ACORN received funding to begin the AIR campaign in November 2003 and immediately begin hiring and training outreach canvassers, tax preparation staff, and management staff in all three cities.

ACORN used IRS statistics and targeted the canvass to zip codes where $40 \%$ of residents claimed the credit. ACORN's research suggested these neighborhoods, some of which already had a high level of ACORN involvement, would have the highest concentration of EITC-eligible families who did not claim the credit. Canvass crews averaged from 10 to 20 canvassers who went door-to-door from 3:00 p.m. to 7:00 p.m. every evening. Canvassers knocked on doors, introduced themselves and informed residents of the free tax preparation services and distributed flyers to every household whether they talked to anyone in the house. The flyers included eligibility criteria and benefit levels for the EITC and child tax credits (CTCs) and promoted the free tax preparation services provided by ACORN and other VITA programs.

In addition to canvassing door-to-door, canvassers sometimes worked public places with high volume of pedestrian traffic of low- and moderate-income people. For instance in Miami, one or two staff canvassed the parking lot of the public welfare department located in Little Haiti. Canvassers also stationed themselves in shopping areas in low- and moderate-income communities. The goals of the canvass included (a) informing residents of EITC benefits and criteria for eligibility, (b) warning families of the predatory lending practices of commercial tax preparation, and (c) telling people they could get their taxes prepared for free at ACORNsponsored VITA sites.

ACORN hired VITA site coordinators in Miami and San Antonio who had previous experience filing taxes and managing VITA sites. The tax preparation staff ACORN hired were trained and credentialed in coordination with the IRS. At the completion of the training, taxprep staff had to pass an IRS examination to be certified to prepare taxes. In Miami and New Orleans, ACORN ran the VITA operation directly out of the ACORN office. In San Antonio, ACORN coordinated its work with an existing citywide VITA coalition that concluded that south San Antonio was underserved with VITA sites. Thus, ACORN created a partnership with Palo Alto College, a 
community college on the south side that they felt was ideal for this purpose. In late December and early January, ACORN staffers completed the VITA training, installed computers, ordered and uploaded the appropriate software, received authorization from the IRS to file taxes electronically, and opened their doors in late January 2004.

\section{METHOD}

\section{Research Questions}

Program officials at the Marguerite Casey Foundation, the three co-principal investigators (co-PIs), and ACORN national staff formulated evaluation questions through a collaborative process. The primary ones this study addresses include the following:

1. How productive were ACORN VITA sites in terms of number of tax returns filed and helping families claim the EITC?

2. Were grassroots outreach methods successful in getting families to file their taxes at ACORN's free tax prep sites?

3. Were the clients of ACORN's VITA sites satisfied with the tax preparation services provided by ACORN?

4. Did ACORN significantly increase the uptake of families claiming the EITC in the low and moderate income communities targeted by the AIR campaign?

5. Was ACORN's model of EITC outreach and VITA sustainable?

\section{Design}

This program evaluation used a mixed-method design drawing on a number of evaluation designs including experimental (Gabor, Unrau, \& Grinnell, 1998; Royse \& Thyer, 1996), empowerment (Fetterman, Kaftarian, \& Wandersman, 1996), program monitoring (Rossi, Freeman, \& Lipsey, 1999), and survey (Fink, 1998).

Because we began the evaluation in late February 2004, 3 months after ACORN initiated canvassing and well into the 2003 tax filing season, it was difficult to implement a quasi-experimental evaluation design. However, because ACORN began canvassing in December 2003 and continued throughout the tax season (January 15 until April 15), canvassers obviously talked to some families before they filed taxes and other families after they filed taxes. If we assume reasonably valid responses to the question "How did you file your taxes this year?" we can simulate a pretest-posttest comparison group design for Research Question 2. For this question, the independent variable is talking to an ACORN canvasser and the dependent variable is method of filing. Any weakness of this pre-experimental design is strengthened by the use of a comparison group. The remaining research questions were answered through a combination of record reviews of IRS and ACORN administrative data and interviews with individuals and focus groups.

Research Question 4 is the most difficult to assess. The only way to answer this question is to have accurate and reliable data on the numbers of families in the targeted communities who qualify for but do not claim the EITC and measure this variable with a pretest and a posttest with the AIR campaign (Canvass outreach \& VITA) serving as the independent variable. Unfortunately, no accurate and reliable measures exist at the local level of families who qualify but do not claim the EITC (Berube, 2003). Although we were unable to directly address this question, using regional IRS statistics, we were able to compare ACORN's success in filing taxes for families claiming the EITC with other VITA sites in the three pilot cities.

The co-PIs conducted individual and focus group interviews with ACORN staff, IRS officials, ACORN VITA site clients, and key informants from other organizations involved in free tax preparation. Between March 1, 2004 and April 15, 2004, one co-PI visited the San Antonio and Miami offices while another visited the New Orleans office, allowing them to observe both outreach efforts and VITA site operations during the tax season.

The research team also contracted with the University of Connecticut's Center for Survey Research and Analysis (CSRA) to conduct a telephone survey of people who had spoken with one of ACORN's door-to-door canvassers. The purpose of the telephone survey was to assess the impact of the canvass on respondent decisions to file taxes for free at a VITA site or pay someone to prepare their taxes (Research Question 2).

\section{Sampling}

Three different types of sampling were used corresponding to the telephone survey, focus group interviews with VITA site clients, and key informant interviews. The sample frame for the telephone survey of canvassed households was provided by ACORN and consisted of a list of households where ACORN canvassers reported speaking to a person. In these households, CSRA spoke to the person who had been canvassed by ACORN. The sample frame for the comparison group of noncanvassed households consisted of a list of all households in ACORN-targeted geographies with a directory-listed telephone number. Households were randomly selected from this list. City residents who reported that they had spoken with an ACORN representative were screened out of this survey and were not interviewed. 
Two focus groups were conducted in each pilot city (total $N=55$ ). The sample frame for focus groups was contact information for all VITA site clients who had filed taxes at ACORN's VITA site (at the point of the site visit) during the 2003 tax season. Clients were randomly selected from these lists. Sixty clients agreed to participate in focus groups and 55 showed up, resulting in a $92 \%$ participation rate. Focus group respondents were paid a $\$ 50$ honorarium.

The co-PIs used purposive sampling to interview key informants about ACORN's performance and collaboration. We contacted the regional IRS offices and interviewed at least one official responsible for IRS VITA site administration in each city. We also interviewed a national IRS administrator responsible for all VITA sites nationally. In Miami and San Antonio, we interviewed three key informants in each city who were managers of nonprofit organizations that were members of VITA coalitions consisting of several nonprofit organizations that work together to support and coordinate expansion of VITA operations.

\section{Measurement Instruments}

Two instruments measured the impact of the canvass on method of filing taxes. The first instrument was the intake form at ACORN VITA sites that prospective clients filled out prior to filing their taxes. The form asked respondents, "How did you hear about ACORN?" Responses to this question included flyer on my door, flyer somewhere else, newspaper, radio or TV, phone call, sign, and word of mouth. We analyzed 2,989 intake forms from ACORN's VITA sites.

The other instrument used to evaluate the canvass was the telephone survey administered to individuals who talked with an ACORN canvasser. The survey was designed by the entire research team in collaboration with CSRA and ACORN staff, and was created to begin during the tax season. The main survey question used in the current evaluation was "How did you file your taxes this year?" Response categories included prepared by self, used ACORN's free tax preparation service, used a free tax preparation service other than ACORN's, and paid a company or a person to prepare your taxes.

Instruments designed to measure client perceptions of the strengths and weaknesses of ACORN's tax preparation services asked clients how they heard about ACORN's VITA, what they liked and did not like about ACORN's tax preparation, suggested improvements, and whether they would use ACORN's VITA again next year.
Interview guides for IRS officials and VITA coalition members included the following questions: "What has ACORN accomplished in the areas of ... door-to-door canvassing and VITA tax preparation?" "Describe anything new/different that ACORN brings to the EITC/ VITA community," and "What kind of partner has ACORN been in the VITA community?"

\section{Data Collection}

A pretest for the New Orleans CSRA telephone survey of canvassed households was conducted with 29 respondents from March 30 to March 31, 2004. The survey was then conducted with another 384 respondents from April 7 to June 25, 2004, for a total of 413 canvassed respondents. The survey of noncanvassed households was administered to $121 \mathrm{New}$ Orleans respondents and was conducted from June 10 to June 28, 2004. The San Antonio survey of canvassed households was conducted with 429 respondents from April 6 to June 16, 2004. The survey of noncanvassed households was administered to 100 San Antonio respondents and was conducted from June 8 to June 23, 2004.

CSRA conducted two surveys in each city: a survey of canvassed households and a survey of noncanvassed households. Both surveys were conducted by telephone from CSRA's centralized interviewing facility in Storrs, Connecticut. They conducted the Miami interviews in English and Spanish.

The co-PIs conducted focus groups with VITA site clients in private rooms at the respective VITA sites. In Miami, one focus group was conducted in Spanish using a translator. The co-PI read the questions to the translator who translated the questions from English to Spanish and respondents answered the questions in Spanish. A bilingual research assistant transcribed the responses in both Spanish and English. Translation services were offered to participants in both San Antonio focus groups that were $100 \%$ Latino/Latina. Everyone stated they were bilingual and did not need translation services. Focus groups were recorded and audio transcribed. All data collection procedures were approved by Georgia State University's Human Subjects Institutional Review Board.

The co-PIs conducted the individual interviews by phone with interview guides. The proceedings of the interviews were either recorded and transcribed or recorded by note taking that the interviewees examined and approved. 


\section{Data Analysis}

Chi square tests were used to analyze results from the telephone survey. Effect sizes were measured with Cramer's V statistics. A .05 $p$ value was used to measure statistical significance.

ACORN's performance in filing taxes and the percentage of ACORN clients claiming the EITC was analyzed by ranking ACORN's performance compared to all other VITA sites in the respective cities. Frequency distributions were used to analyze administrative data from VITA site intake forms. Focus group and individual interview data were analyzed using the constant comparative method (Strauss \& Corbin, 1990).

\section{Limitations}

A simulated pre-experimental design does not allow us to assert causal inference between independent and dependent variables. The lack of valid and reliable measures for the numbers of families who potentially qualify but do not claim EITC (Berube, 2003) make it impossible to even design an experimental evaluation of this important variable. We do not know how valid and reliable the data are from the VITA site intake forms. Although these forms appear to have face validity, they were not designed by the research team and we have no validity and reliability measures for them. The $\$ 50$ honorarium might have influenced some focus group participants to respond in a manner they thought would please the researchers. However, offering a modest honorarium when doing research in low and moderate income communities is a common practice. The differences for some demographic variables between the canvassed group and the comparison group are another weakness.

\section{RESULTS}

\section{Research Question 1: How Productive Were Acorn Vita Sites in Terms of Number of Tax Returns Filed and Helping Families Claim the EitC?}

The mixed-method evaluation process provided data that supported the conclusion that the AIR program produced a significant increase in free tax filings and EITC participation in the targeted areas.

According to regional IRS reports (see Table 1) during the 2003 tax season, ACORN VITA sites filed 3,481 tax returns resulting in $\$ 3.9$ million of EITC and CTC refunds for low-income families. In New Orleans, ACORN filed more tax returns than any other VITA site
TABLE 1: ACORN VITA Site Statistics by City (Tax year 2003)

\begin{tabular}{lrrcc}
\hline Site & $\begin{array}{c}\text { Total } \\
\text { Returns }\end{array}$ & $\begin{array}{r}\text { Total \$ EITC } \\
\text { and CTC at } \\
\text { ACORN Site }\end{array}$ & $\begin{array}{c}\text { Number } \\
\text { of VITA } \\
\text { Sites in City }\end{array}$ & $\begin{array}{c}\text { ACORN } \\
\text { Rank } \\
\text { (\# returns) }\end{array}$ \\
\hline San Antonio & 1,237 & $\$ 1,446,121$ & 27 & 3 \\
Miami & 610 & $\$ 523,941$ & 39 & 1 \\
New Orleans & 1,634 & $\$ 1,940,327$ & $65^{\mathrm{a}}$ & 1 \\
Totals & 3,481 & $\$ 3,910,389$ & & \\
\hline
\end{tabular}

NOTE: Totals are from IRS reports of electronically filed tax returns. ACORN = Association of Community Organizations for Reform Now; VITA = voluntary income tax assistance; EITC = earned income tax credit; $\mathrm{CTC}=$ child tax credit.

a. Number of VITA sites in all of Louisiana.

in Louisiana. The ACORN Miami VITA site was ranked first among 39 VITA sites in the metropolitan area. The ACORN San Antonio VITA site ranked third out of 27 VITA sites in the city. The only VITA sites in San Antonio that outperformed ACORN were run by the IRS and the City of San Antonio. All informants reported that this level of performance was unprecedented for first-year operations.

IRS officials stated that these performances were outstanding, especially for 1st-year VITA sites. An IRS official in Texas described ACORN's San Antonio VITA operation:

From a late start ACORN got a first class [VITA] operation up and running at Palo Alto College. ACORN's Director seemed to have a very good vision of where she wanted to go and that made me feel comfortable. It all happened in 8 weeks, which is an enormous task to hire, train, get the software, and be ready for the public on January 15 ! I was amazed at how quickly she did it! I am even more amazed at the volume [of returns] they are doing. I have over 900 returns from ACORN's site. I give her an A+ for a start-up operation.

An IRS official in Louisiana stated that the New Orleans ACORN VITA site was "amazing for a first year." ACORN far exceeded her expectations, in spite of getting started in late November to early December, instead of the customary late summer or early fall. She stated that success grows out of public awareness. ACORN's various forms of grassroots outreach generated 1,600 clients, rather than the usual 100 to 200 . She added that one of the biggest hurdles new VITA sites must overcome is reluctance among potential clients: building trust.

ACORN VITA sites processed a high percentage of clients filing for the EITC. As Table 2 shows, in all three cities, a higher percentage of clients at ACORN's VITA sites claimed the EITC compared to the citywide average of all VITA sites. Sixty percent of clients at ACORN's Miami VITA claimed the EITC; this was a $46 \%$ increase over the citywide average of $41 \%$. These higher 
percentages are probably a reflection of targeting the canvass in zip codes with high EITC eligibility.

\section{Research Question 2: Were Grassroots Outreach Methods Successful in Getting Families to File Their Taxes at Acorn's Free Tax Prep Sites?}

Data from the telephone survey, intake forms from ACORN's VITA sites, and key informant interviews suggest that ACORN's door-to-door canvass was effective at influencing tax payer decisions to file at a VITA rather than use a commercial tax preparer.

Table 3 shows the demographic variables for both the canvassed (experimental) and noncanvassed (comparison) groups in New Orleans and San Antonio. No differences

TABLE 2: $\quad$ Proportion of Clients Filing for EITC at ACORN VITA Sites Compared to Averages of VITA Sites Citywide

\begin{tabular}{|c|c|c|c|}
\hline City & $\begin{array}{c}\% \text { ACORN } \\
\text { VITA }\end{array}$ & $\begin{array}{c}\text { City-Wide } \\
\% \text { VITA } \\
\text { Average }\end{array}$ & $\%$ Increase \\
\hline New Orleans & 54 & 44 & 23 \\
\hline Miami & 60 & 41 & 46 \\
\hline San Antonio & 51 & 44 & 16 \\
\hline
\end{tabular}

NOTE: Figures are from IRS regional reports.

ACORN = Association of Community Organizations for Reform Now; VITA = voluntary income tax assistance; EITC = earned income tax credit. were found between the canvassed group and the comparison group in either city for level of education or for gender. In New Orleans, both groups were virtually the same for income; but in San Antonio, the comparison group had higher incomes. In San Antonio, $43.8 \%$ of the comparison group earned more than $\$ 30,000$ a year compared to only $25.7 \%$ of the canvassed group. In both cities, there were differences between the canvassed group and the comparison group for both age and race. In San Antonio, $94 \%$ of the canvassed group was Hispanic compared to $67 \%$ of the comparison group. In New Orleans, $91 \%$ of the canvassed group was Black compared to $73 \%$ of the comparison group.

Results from the telephone survey suggest ACORN's canvass had an impact on the decisions of families about where to file their taxes (see Tables 4 and 5). In both New Orleans and San Antonio, when comparing method of tax filing between individuals who were canvassed before filing taxes with individuals canvassed after filing taxes, those who filed after being canvassed were more likely to file at a VITA and less likely to pay a person or company to file their taxes. Fifty four percent of respondents in San Antonio and New Orleans who filed their taxes before they were canvassed paid commercial services to prepare their taxes, whereas only $37 \%$ and $25 \%$ respectively of those canvassed prior to filing their taxes used commercial preparers. In New Orleans, being canvassed appeared

TABLE 3: Demographic Variables for Canvassed and Comparison Groups (Telephone Survey)

\begin{tabular}{|c|c|c|c|c|}
\hline \multirow[b]{2}{*}{ Variable } & \multicolumn{2}{|c|}{ San Antonio } & \multicolumn{2}{|c|}{ New Orleans } \\
\hline & $\begin{array}{c}\% \text { Canvassed } \\
(n=429)\end{array}$ & $\begin{array}{l}\% \text { Comparison } \\
\quad(n=100)\end{array}$ & $\begin{array}{c}\% \text { Canvassed } \\
(\mathrm{n}=413)\end{array}$ & $\begin{array}{c}\% \text { Comparison } \\
(\mathrm{n}=121)\end{array}$ \\
\hline \multicolumn{5}{|l|}{ Race $^{a}$} \\
\hline Black & 0.9 & 5.0 & 90.8 & 72.7 \\
\hline White & 3.0 & 19.0 & 2.4 & 10.7 \\
\hline Hispanic & 93.9 & 67.0 & 0.5 & 2.5 \\
\hline Other or refused & 2.0 & 3.3 & 6.2 & 14.0 \\
\hline \multicolumn{5}{|l|}{$\mathrm{Age}^{\mathrm{a}}$} \\
\hline 18 to 30 & 24.3 & 21.6 & 27.9 & 17.7 \\
\hline 31 to 50 & 52.2 & 40.2 & 49.5 & 38.1 \\
\hline 51 or older & 23.6 & 38.1 & 22.6 & 44.2 \\
\hline \multicolumn{5}{|l|}{ Education } \\
\hline$<$ high school grad & 34.0 & 29.3 & 19.6 & 16.4 \\
\hline High school grad & 42.1 & 36.4 & 47.5 & 43.1 \\
\hline Post-high school & 23.9 & 34.3 & 32.9 & 40.5 \\
\hline \multicolumn{5}{|l|}{ Income $^{b}$} \\
\hline$<20 \mathrm{k}$ a year & 43.1 & 27.5 & 50.8 & 52.6 \\
\hline 20 to $30 \mathrm{k}$ a year & 31.2 & 28.8 & 26.7 & 26.8 \\
\hline $30 \mathrm{k}$ or more a year & 25.7 & 43.8 & 22.5 & 20.6 \\
\hline \multicolumn{5}{|l|}{ Gender } \\
\hline Male & 33.8 & 42.0 & 36.1 & 27.3 \\
\hline Female & 66.2 & 58.0 & 63.9 & 72.7 \\
\hline
\end{tabular}

NOTE: ACORN = Association of Community Organizations for Reform Now; VITA = voluntary income tax assistance; EITC = earned income tax credit.

a. Chi Square $p$ value $<.05$ for San Antonio and New Orleans. b. Chi Square $p$ value $<.05$ for San Antonio only. 
TABLE 4: Crosstabulation: Method of Tax Preparation by Whether Filed Before or After Being Canvassed (New Orleans)

\begin{tabular}{|c|c|c|}
\hline \multirow[b]{2}{*}{ Method of Tax Preparation } & \multicolumn{2}{|c|}{$\begin{array}{l}\text { When Did You Prepare } \\
\text { and File Your Taxes? }\end{array}$} \\
\hline & $\begin{array}{c}\text { Filed Before } \\
\text { Being } \\
\text { Canvassed } \\
(\mathrm{n}=118)\end{array}$ & $\begin{array}{l}\text { Filed After } \\
\text { Being } \\
\text { Canvassed } \\
(\mathrm{n}=217)\end{array}$ \\
\hline$\%$ prepared by self & 23.7 & 27.2 \\
\hline $\begin{array}{l}\% \text { prepared by ACORN or other } \\
\text { free tax service } \\
\% \text { paid a person or company to }\end{array}$ & 22.0 & 45.6 \\
\hline $\begin{array}{l}\text { prepare taxes } \\
\% \text { totals }\end{array}$ & $\begin{array}{c}54.2 \\
100\end{array}$ & $\begin{array}{c}27.2 \\
100\end{array}$ \\
\hline
\end{tabular}

NOTE: $\chi^{2}(2, N=335)=26.98, p=.000$, Cramer's $V=.28$. ACORN $=$ Association of Community Organizations for Reform Now.

TABLE 5: Crosstabulation: Method of Tax Preparation by Whether Filed Before or After Being Canvassed (San Antonio)

\begin{tabular}{lcc}
\hline & \multicolumn{2}{|c}{$\begin{array}{c}\text { When Did You Prepare } \\
\text { and File Your Taxes? }\end{array}$} \\
\cline { 2 - 3 } & $\begin{array}{c}\text { Filed Before } \\
\text { Being } \\
\text { Canvassed } \\
(\mathrm{n}=224)\end{array}$ & $\begin{array}{c}\text { Filed After } \\
\text { Being } \\
\text { Canvassed } \\
(\mathrm{n}=143)\end{array}$ \\
$\begin{array}{l}\text { Method of Tax Preparation } \\
\text { \% prepared by self }\end{array}$ & 26.3 & 38.5 \\
$\begin{array}{l}\text { \% prepared by ACORN or other } \\
\text { free tax service } \\
\text { prepare taxes }\end{array}$ & 18.3 & 23.1 \\
\% totals & 55.4 & 38.5 \\
\hline
\end{tabular}

NOTE: $\chi^{2}(2, N=367)=10.22, p=.006$, Cramer's $V=.17$. ACORN $=$ Association of Community Organizations for Reform Now.

to cut in half the number of families selecting a commercial preparation company. Also, in New Orleans, talking to an ACORN canvasser doubled (22\% to $44 \%$ ) the likelihood of a family using a VITA as opposed to paying for tax preparation. These data suggest the canvass in New Orleans was particularly effective in influencing taxpayer decisions to use VITA rather than commercial tax preparation companies.

Tables 6 and 7 compare method of tax preparation between individuals who filed taxes after talking to an ACORN canvasser with a noncanvassed comparison group for New Orleans and San Antonio respectively. In New Orleans, individuals canvassed by ACORN were five times more likely ( $45.6 \%$ to $9.3 \%$ ) to use a free tax preparation service compared to those who were not canvassed. In San Antonio, canvassed individuals were
TABLE 6: Crosstabulation: Method of Tax Preparation Between Individuals Canvassed by ACORN and a Comparison Group Not Canvassed by ACORN (New Orleans)

\begin{tabular}{lcc}
\hline & \multicolumn{2}{c}{$\begin{array}{c}\text { Comparison Group or } \\
\text { Canvassed Group }\end{array}$} \\
\cline { 2 - 3 } & $\begin{array}{c}\text { Not } \\
\text { Canvassed } \\
\text { Comparison } \\
\text { Group } \\
(\mathrm{n}=86)\end{array}$ & $\begin{array}{c}\text { Canvassed } \\
\text { by ACORN } \\
(\mathrm{n}=217)\end{array}$ \\
\hline $\begin{array}{l}\text { Method of Tax Preparation } \\
\text { \% prepared by self }\end{array}$ & 31.4 & 27.2 \\
frep tax service & 9.3 & 45.6 \\
$\begin{array}{l}\text { prepare taxes } \\
\text { prep totals }\end{array}$ & 59.3 & 27.2 \\
\hline
\end{tabular}

NOTE: $\chi^{2}(2, N=303)=40.89, p=.000$, Cramer's $V=.37$. ACORN $=$ Association of Community Organizations for Reform Now.

TABLE 7: Crosstabulation: Method of Tax Preparation Between Individuals Canvassed by ACORN and a Comparison Group Not Canvassed by ACORN (San Antonio)

\begin{tabular}{lcc}
\multicolumn{2}{c}{ Group Not Canvassed by ACORN (San Antonio) } \\
\hline & \multicolumn{2}{c}{$\begin{array}{c}\text { Comparison Group or } \\
\text { Canvassed Group }\end{array}$} \\
\cline { 2 - 3 } & $\begin{array}{c}\text { Not } \\
\text { Canvassed } \\
\text { Comparison } \\
\text { Group } \\
(\mathrm{n}=81)\end{array}$ & $\begin{array}{c}\text { Canvassed } \\
\text { by ACORN } \\
\text { (n = 143) }\end{array}$ \\
\hline $\begin{array}{l}\text { Method of Tax Preparation } \\
\text { \% prepared by self }\end{array}$ & 49.4 & 38.5 \\
$\begin{array}{l}\text { \% paid a person or company to } \\
\text { prepare taxes }\end{array}$ & 8.6 & 23.1 \\
\% totals & 42.0 & 38.5 \\
\hline
\end{tabular}

NOTE: $\chi^{2}(2, N=224)=7.65, p=.022$, Cramer's $V=.19$.

ACORN $=$ Association of Community Organizations for Reform Now.

approximately three times more likely $(23.1 \%$ to $8.6 \%)$ to use a free tax service compared to those not canvassed. In New Orleans, individuals who were canvassed were half as likely to pay for tax preparation $(27.2 \%$ to $59.3 \%)$ compared to the noncanvassed comparison group. This is significant because the comparison group in New Orleans was virtually identical to the control group in terms of income and education.

Because most clients at ACORN's VITA sites were first-time VITA users, we analyzed 2,989 intake forms to determine where families had filed their 2002 tax returns. Forty five percent of Miami VITA site clients, $25 \%$ of New Orleans clients and 36\% of San Antonio clients paid someone (or a company) to prepare their 2002 tax return. 
TABLE 8: How ACORN VITA Clients Heard About Free Tax Preparation

\begin{tabular}{lccc}
\hline Method of Hearing & $\begin{array}{c}\text { San Antonio } \\
(\mathrm{n}=1,138)\end{array}$ & $\begin{array}{c}\text { New Orleans } \\
(\mathrm{n}=1,214)\end{array}$ & $\begin{array}{c}\text { Miami } \\
(\mathrm{n}=637)\end{array}$ \\
\hline \% flyer at home & 6.1 & 14.1 & 9.6 \\
\% flyer somewhere else & 34.2 & 8.0 & 33.6 \\
\% word of mouth & 30.9 & 32.0 & 30.0 \\
\% radio or TV & 13.1 & 12.7 & 8.5 \\
\% phone call & 1.2 & 12.1 & 3.1 \\
\% sign or billboard & 4.5 & 11.1 & 5.0 \\
\% other & 11.0 & 10.0 & 10.2 \\
\% totals & 100.0 & 100.0 & 100.0 \\
\hline
\end{tabular}

NOTE: Data are from intake forms clients filled out at ACORN VITA sites. Other category includes newspaper advertisement, church, place of work, and store or business.

ACORN = Association of Community Organizations for Reform Now; VITA = voluntary income tax assistance.

Fees for this service ranged up to $\$ 400$ and, in New Orleans, averaged $\$ 130$. The inference from these data suggests the canvass significantly influenced people to switch from commercial preparation in 2002 to VITA in 2003.

Further analysis of intake forms indicates that in San Antonio and Miami receiving a flyer somewhere other than a respondent's house were the most likely places to have heard about ACORN's VITA. Word-of-mouth was the second most popular method in Miami and San Antonio but, in New Orleans, was the most frequently cited method of hearing about VITA services (see Table 8).

In San Antonio, ACORN canvassers distributed 50,000 flyers that included the addresses of all VITA sites in the city. VITA sites in San Antonio filed taxes for 9,000 more families in 2004 compared to 2003 . The total number of clients went from 14,000 in 2003 to 23,000 the following year. Members of San Antonio's VITA coalition and an IRS official believed ACORN's canvass was a critical factor in a $64 \%$ city-wide increase of VITA clients between 2003 and 2004. Several members of San Antonio's citywide VITA coalition believed ACORN's canvass may have been responsible for a $115 \%$ annual increase from 2003 to 2004 in calls to United Way's 211 help line inquiring about free tax preparation. An administrator at the United Way of San Antonio reported that VITA calls on United Way's 211 Help Line went from 3,306 in 2003 to 7,130 in 2004. She believed ACORN's outreach was an important factor in 211 calls going up during the past year.

On an additional note, the New Orleans office employed an autodialer and two very prominent billboards to augment their canvass. The focus groups and intake forms indicate these were very effective methods.
According to intake forms, $23 \%$ of clients were attracted by the signs and autodialer combined.

A vast majority of clients at ACORN VITAs were firsttime VITA users. Analysis of intake forms from ACORN VITA sites showed that only $10 \%$ of Miami clients, $13 \%$ of New Orleans clients, and 19\% of San Antonio's VITA clients used VITA services to file 2002 tax returns.

\section{Research Question 3: Were the Clients of Acorn's Vita Sites Satisfied With the Tax Preparation Services Provided by Acorn?}

During site visits, we conducted two focus groups per city with clients who had filed their taxes at ACORN VITA sites. We interviewed a total of 55 VITA clients in six focus groups. Overall, clients were very satisfied with the tax preparation services they received at ACORN. The no-cost service was the most popular aspect of VITA. Clients also gave ACORN tax preparers high marks for customer service. Clients felt the tax prep specialists at ACORN were friendly, professional, reasonably expeditious, and open to questions. Several focus group members compared ACORN VITA staff favorably to the staff of commercial preparation companies they had used before. One client from New Orleans stated, "I thought [ACORN's tax preparation staff] were very polite and confidential. I got [my refund] in a timely manner and they even treated me with respect even though the service was free." Another client from New Orleans received the EITC this year but stated last year, a commercial preparer did not screen her to see if she qualified for the EITC.

Clients from all three cities were satisfied with the location of the VITA sites and the days and hours they were open for business. In New Orleans and Miami, ACORN operated VITA directly out of their own offices. Both sites were on major bus lines and were very easy to find. In San Antonio, the citywide VITA coalition stated the area that needed a VITA site the most was south San Antonio (a previous south side VITA site had closed). ACORN negotiated a partnership with Palo Alto College, a community college in the heart of south San Antonio easily accessible by bus. Although this site was five miles from the ACORN office, it proved to be an ideal location and a very productive site. All ACORN VITA sites were open on weekends and evenings. Several clients stated Sundays were the only day off they had to come in and file their taxes.

Clients also felt the tax preparers did everything possible to get them the maximum refund. One or two people in each focus group stated they received a larger refund this year compared to last year. A client from Miami 
stated that a Jackson Hewitt tax specialist did not tell her she could deduct childcare expenses when she filed her 2002 taxes. Her refund doubled from $\$ 1,200$ to $\$ 2,500$ dollars between last year and this year. Several clients had paid Jackson Hewitt or H\&R Block \$200 to $\$ 300$ to file their 2002 taxes and were very pleased to have used VITA this year.

In all three cities, the race and ethnicity of the tax prep staff reflected the constituency being served. Clients were pleased with the racial, ethnic, and language diversity of the tax-prep staff. In San Antonio the entire tax prep staff including the supervisor was bilingual. Miami clients noted that the tax preparers spoke their language and made them feel comfortable. A New Orleans client stated,

\begin{abstract}
This particular program seems more community-oriented and they treat you more personal compared to where I went. I really like the atmosphere. Another thing, the Federal Building? It seems to me that you all move faster than at the Federal Building. You go over there to get your taxes. You don't have to wait all this time. Even though they're doing it for free, you get out of here more quicker than up there.
\end{abstract}

Few clients had criticisms or suggested improvements, but some felt as if they waited a long time to see a tax specialist. They were hesitant to complain about a free service, but some clients waited an hour or more to see a tax preparer. One person stated the upfront screening should have been more thorough. He had waited a couple of hours and when he finally saw a tax specialist, he was told he did not have the proper paper work and would have to return another day to complete his return. In New Orleans, some clients complained about the cramped office space and waiting area. To its credit, ACORN management made adjustments during the tax season to improve customer satisfaction. For example, in San Antonio, the original space in Palo Alto College was out in the library and did not afford adequate privacy for tax preparation. After a few days, tax preparation moved to a classroom that allowed for more privacy and space to adequately address client needs. In New Orleans, they adjusted hours and staffing to accommodate clients during the most convenient and busiest times of the week.

\section{Research Question 4: Did Acorn Significantly Increase the Uptake of Families Claiming the EITC in the Communities Targeted by the Air Project?}

As previously described in the methods section, no valid and reliable measures exist to definitively answer this question, but data from a variety of sources suggest the AIR campaign probably stimulated EITC participation in the three cities.
The high percentage of ACORN VITA clients claiming the EITC (Table 2) compared to city-wide averages in all three cities suggests ACORN's canvass was accurately targeting zip codes of EITC-eligible tax payers. The percentages of ACORN filers qualifying for EITC (ranging from $51 \%$ in San Antonio to $60 \%$ in Miami) is substantially higher than the $21 \%$ average measured in VITA sites in 27 cities and rural areas that participated in a campaign to increase the EITC uptake by the National Tax Assistance for Working Families campaign in 2000 (Berube, 2003).

In Miami, $25 \%$ of all ACORN VITA clients did not file taxes during the previous tax season. Also, $60 \%$ of the clients at Miami's VITA filed for 2003 EITC. Extrapolating these figures suggests that approximately 92 families, or $15 \%$ of all clients at Miami ACORN's VITA, were firsttime EITC filers.

The New Orleans office was moderately successful identifying families who qualified for previous years' EITC or CTC. The New Orleans VITA filed amended 2001 and 2002 returns for 284 families claiming EITC or CTC. These families received tax credits totaling $\$ 122,683$ from these amended returns. Finding these families and assisting them in filing for back EITC has been one of the more difficult challenges for ACORN. The flyer distributed by canvassers mentioned families may qualify for tax credit refunds from 2001 and 2002. Because of the announcement on the flyer, some families brought in tax returns from prior years when they came in to file their 2003 taxes. This allowed the tax specialists to screen them for past EITC and CTC eligibility. During the tax season, 207 families qualified for back EITC. Amended returns had to be completed and filed on paper as opposed to electronically, adding significantly to the workload of the staff.

Since the tax season, organizers in New Orleans included past EITC eligibility flyering in their regular door knocking, voter registration, and a housing fair event. A September press conference on the issue received extensive television coverage and generated more clients coming in the door for screening. Since April 15, the New Orleans VITA has also filed 2003 tax returns for 182 families resulting in more than $\$ 50,000$ of combined EITC and CTC tax credits.

\section{Research Question 5: Was Acorn's Model of EITC Outreach and VITA Sustainable?}

Although a comprehensive answer to this question will take several years of data points, initial findings from TY 2004 suggest the model is sustainable. For TY 2004, 
ACORN did EITC outreach and ran VITA sites in 51 cities. At these 51 VITA sites, ACORN prepared taxes for 18,810 low- and moderate-income families who received more than $\$ 9$ million in EITC and more than $\$ 19$ million in total tax refunds. From TY 2003 to TY 2004, San Antonio and Miami increased the number tax returns filed to 1,945 and 738 respectively, whereas New Orleans filed taxes for 1,170 families (down from 1,634 last year).

For TY 2004, ACORN raised money for EITC outreach and VITA from a variety of sources. Although no office in 2005 had as much financial support as last year's Marguerite Casey Grant provided, some offices successfully raised money from a wide variety of national and local sources.

San Antonio increased VITA production by $57 \%$ and was the highest performing ACORN VITA in TY 2004. Several factors contributed to this success. San Antonio ACORN raised a total of more than $\$ 40,000$ from several local banks, credit unions, social service agencies, and one local grocery store. They also received money from ACORN's national agreement with H\&R Block to do EITC outreach. Another nationwide agreement between ACORN and Citigroup provided funding for EITC outreach and VITA services. The new funds were used to stabilize EITC outreach and expand the VITA operation. The head organizer rehired several tax specialists from 2003 and promoted the most talented one to supervise the site. Her tax specialists, were hired, trained, and IRS certified earlier than last year, allowing the VITA to open a week earlier compared to last year. Maintaining the same location at Palo Alto College was also a factor. Twenty six percent ( $n=328$ ) of 2003 clients came back in 2004, and 761 new clients found out about the service by signage posted on the community college campus. As was the case in 2003, being the only VITA site in south San Antonio probably helped boost productivity in 2004. San Antonio's 57\% increase in productivity is noteworthy, considering they did not have the funding to field an extensive door-to-door canvass. ACORN organizers passed out flyers (promoting all VITA sites in San Antonio) during their routine nightly door knocking, but this outreach was not as extensive as the 2003 canvass.

\section{DISCUSSION AND APPLICATIONS TO SOCIAL WORK PRACTICE}

The program evaluation data provided evidence that ACORN's community organizing techniques were effective in providing an important service to low-income working people in the three pilot cities. The most robust finding in this evaluation is the dramatic influence that door-to-door canvassing appears to have on influencing low-income tax payer decisions about where to seek help with tax preparation. Canvassed respondents in New Orleans were five times more likely to choose free tax preparation compared to an income equivalent comparison group. This finding builds on previous experimental designs that found door-to-door canvassing was highly effective in mobilizing citizens to vote (Gerber \& Green, 2000; Green, Gerber, \& Nickerson, 2003).

Most models of community organization practice treat social action and service delivery as two different phenomena (Fisher, 2005; Rothman, 2001). One is designed to foment change by organizing community members against enemy targets who are exploiting the community. The other addresses human need by delivering resources to clients and constituents. With significantly different organizational cultures-service agencies are usually much more formalized, hierarchical, and mainstreamsocial action and service do not co-exist easily in single organizations. The divide is more stark in community organizing that occurs outside of the field of social work (Brown, 1997; McKnight, 1995). Community organizers, such as those in ACORN, have historically seen service as a depoliticized, individual-based form of social work, one very different from the highly politicized, base-building, social change work that is their core strategy (for more on the issue of combining services and organizing, see Brooks, 2005).

This study demonstrates, as others have before (Brooks, 2005; Fisher \& Karger, 1997) that there are significant linkages between social action and service delivery. In this case, the door-to-door community organizing that is the essence of ACORN's model increased the effectiveness of the AIR campaign. It gave them on-theground contacts and connections in the surrounding area, embedded them in the community and beyond the service site, and applied proven door-to-door canvassing techniques to provide outreach. Conversely, the service delivery approach complemented ACORN's organizing efforts. It enabled ACORN to provide resources and a valuable service to individual members and other community residents. This helped ACORN strengthen its position and expand its visibility in the community, helping ACORN improve community connectedness to the organization. It also helped ACORN expand its repertoire of strategies and tactics, going beyond direct action. And it served as the basis for significant fundraising for ACORN, which was now able not only to hire canvassers to do outreach for ACORN in low-income communities but also to support a national campaign against RALs. 
Other models for the successful integration of social action and service delivery exist in women-oriented agencies doing work around domestic violence or gayoriented activism around AIDs (Fisher \& Karger, 1997). There are even precedents in ACORN; ACORN Housing division has delivered significant resources, built the organization, and raised funds for it. But what this study reveals is a maturation of the relationship between the two-that is, an understanding in a group such as ACORN that although their core work remains organizing, related, and connected, service work can both benefit from organizing as well as contribute to it. As funding for social change becomes less available and as ACORN matures in its fourth decade of existence, this relationship should strengthen and deepen, both explicitly and implicitly in the organization, modifying the organization's culture and increasing its power and effectiveness. It is not surprising that in 2005, in response to the success of their EITC work in 2004, ACORN opened VITA sites in 51 cities.

\section{REFERENCES}

Adamson, M., \& Borgos, S. (1984). This mighty dream: Social protest movements in the United States. Boston: Routledge \& Kegan Paul.

Atlas, J., \& Dreier, P. (2003, May/June). Enraging the right. Shelterforce Online. Retrieved January 12, 2004, from http:// www.nhi.org/online/issues/129/ACORN.html

Berube, A. (2003, January). Rewarding work through the tax code: The power and potential of the earned income tax credit in 27 cities and rural areas. Center on Urban and Metropolitan Policy, 1-44. Retrieved on June 13, 2005 from http://www.brookings.edu/es/ urban/publications/berubetaxcode.htm.

Berube, A., Kim, A., Forman, B., \& Burns, M. (2002, May). The price of paying taxes: How tax preparation and refund loan fees erode the benefits of the EITC. The Brookings Institution and The Progressive Policy Institute Survey Series, 1-24. Retrieved on June 13, 2005 from http://www.brookings.edu/es/urban/publications/ berubekimeitcexsum.htm

Beverly, S. G. (2002). What social workers need to know about the earned income tax credit. Social Work, 47, 259-266.

Brooks, F. (2001). Innovative organizing practices: ACORN's campaign in Los Angeles organizing workfare workers. Journal of Community Practice, 9, 65-86.

Brooks, F. (2005). Resolving the dilemma between organizing and services: Los Angeles ACORN's welfare advocacy. Social Work, 50, 262-270.

Brooks, F. (in press). Racial diversity on ACORN's organizing staff, 1970-2003. Administration in Social Work.

Brown, M. (1997). Replacing citizenship: AIDS activism and radical democracy. New York: Guilford.

Center on Budget and Policy Priorities. (2004). Facts about the earned income credit: Tax time can pay for working families. Washington,
DC: Author. Retrieved June 13, 2005, from http://www.cbpp.org/ eic2005/eic05-factbook.pdf

Delgado, G. (1986). Organizing the movement: The roots and growth of ACORN. Philadelphia: Temple University Press.

Fetterman, D. M., Kaftarian, S. J., \& Wandersman, A. (Eds.). (1996). Empowerment evaluation: Knowledge and tools for self-assessment and accountability. Thousand Oaks, CA: Sage.

Fink, A. (1998). How to conduct surveys: A step by step guide (2nd ed.). Thousand Oaks, CA: Sage.

Fisher, R. (1994). Let the people decide: Neighborhood organizing in America (Rev. ed.) Boston: Twayne.

Fisher, R. (2005). History, context, and emerging issues for community practice. In M. Weil (Ed.), The handbook of community practice (pp. 34-58). Thousand Oaks, CA: Sage.

Fisher, R., \& Karger, J. (1997). Social work and community in a private world: Getting out in public. White Plains, NY: Longman.

Gabor, P. A., Unrau, Y. A., \& Grinnell, R. M. (1998). Evaluation for social workers: A quality improvement approach for the social services (2nd ed.). Boston: Allyn \& Bacon.

Gerber, A. S., \& Green, D. P. (2000). The effects of canvassing, telephone calls, and direct mail on voter turnout: A field experiment. American Political Science Review, 94, 653-663.

Green, D. P., Gerber, A. S., \& Nickerson, D. W. (2003). Getting out the vote in local elections: Results from six door-to-door canvassing experiments. Journal of Politics, 65, 1083-1096.

Hotz, V. J., \& Scholz, J. K. (2001). The earned income tax credit. (Working paper no. 8078). Cambridge, MA: National Bureau of Economic Research.

Kest, S., \& Rathke, W. (1979). ACORN: An overview. Community Organizing Handbook No. 2. New Orleans, LA: Arkansas Institute for Social Justice.

Llobrera, J., \& Zahradnik, B. (2004). A hand up: How state earned income tax credits help working families escape poverty in 2004. Washington, DC: Center on Budget and Policy Priorities.

McKnight, J. (1995). The careless society: Community and its counterfeits. New York: Basic Books.

Phillips, K. R. (2001). The earned income tax credit: Knowledge is money. Political Science Quarterly, 116, 413-423.

Rossi, P. H., Freeman, H. E., \& Lipsey, M. W. (1999). Evaluation: A systematic approach (6th ed.). Thousand Oaks, CA: Sage.

Rothman, J. (2001). Approaches to community intervention. In J. Rothman, J. Erlich, \& J. E. Tropman (Eds.), Strategies of community intervention, (6th ed., pp. 27-64). Itasca, IL: F. E. Peacock.

Royse, D., \& Thyer, B. A. (1996). Program evaluation: An introduction. Chicago: Nelson Hall.

Russell, D. (1990). Political organizing in grassroots politics. Lanham, MD: University Press of America.

Smeeding, T. M., Phillips, K. R., \& O'Conner, M. (2000). The EITC: Expectation, knowledge, use, and economic and social mobility. National Tax Journal, 53, 1187-1209.

Scholz, J. K. (1994). The earned income tax credit: Participation, compliance, and antipoverty effectiveness. National Tax Journal, 47, 63-87.

Scholz, J. K., \& Levine, K. (2000). The evolution of income support in recent decades. In S. H. Danziger \& R. H. Haveman (Eds.), Understanding poverty (pp. 193-228). Cambridge, MA: Harvard University Press.

Staples, L. (2004). Roots to power: A manual for grassroots organizing (2nd ed.). Westport, CT: Praeger. 
Stein, A. (1986). Between organization and movement: ACORN and the Alinsky model of community organizing. The Berkeley Journal of Sociology, 31, 93-115.

Strauss, A., \& Corbin, J. (1990). Basics of qualitative research: Grounded theory procedures and techniques. Newbury Park, CA: Sage.

U.S. General Accounting Office. (2001, December 14). Earned income tax credit eligibility and participation (GAO-02-290R). Washington, DC: Author.

U.S. General Accounting Office. (2005, March). Means-tested programs: Information on program access can be an important management tool (GAO-05-221). Washington, DC: Author. Retrieved June 13, 2005, from http://www.gao.gov/new.items/ d05221.pdf

Ventry, D. J. (2000). The collision of tax and welfare politics: The political history of the earned income tax credit, 1969-99. National Tax Journal, 53, 983-1026.

Wu, C. C., Fox, J. A., \& Reunart, E. (2002). Tax preparers peddle high priced tax refund loans. Washington, DC: The Consumer Federation of America and the National Consumer Law Center. 